\title{
Ecological responses of semi-natural grasslands to abandonment: case studies in three mountain regions in the Eastern Alps
}

\author{
Andreas Bohner • Johannes Karrer • \\ Ronnie Walcher • David Brandl • Kerstin Michel • \\ Arne Arnberger • Thomas Frank • Johann G. Zaller $\mathbb{D}$
}

Received: 31 July 2018 /Revised: 15 July 2019 / Accepted: 28 July 2019/Published online: 21 January 2020

(C) The Author(s) 2020

\begin{abstract}
Semi-natural, extensively managed, grasslands are among the most species-rich agroecosystems in Europe. However, they are threatened by abandonment. We investigated the response of semi-natural grasslands to cessation of mowing at ten sites in three UNESCO Biosphere Reserves in Switzerland and Austria. We assessed vegetation characteristics, topsoil properties and microbially mediated soil processes by comparing once-a-year mowed with adjacent long-term abandoned grasslands on semi-dry, nutrient-poor, baserich soils. Plant litter decomposition was determined using standardized substrates (Tea Bag Index). Soil microbial community composition was assessed by
\end{abstract}

Electronic supplementary material The online version of this article (https://doi.org/10.1007/s12224-019-09355-2) contains supplementary material, which is available to authorized users.

A. Bohner

Agricultural Research and Education Centre

Raumberg-Gumpenstein, Irdning-Donnersbachtal, Styria, Austria

J. Karrer $\cdot$ R. Walcher $\cdot$ D. Brandl $\cdot$ T. Frank $\cdot$

J. G. Zaller $(\bowtie)$

Institute of Zoology, University of Natural Resources and Life

Sciences Vienna (BOKU), Vienna, Austria

e-mail: johann.zaller@boku.ac.at

K. Michel

Federal Research and Training Centre for Forests, Natural Hazards and Landscape, Vienna, Austria

\section{A. Arnberger}

Institute of Landscape Development, Recreation and Conservation Planning, University of Natural Resources and Life Sciences

Vienna, Vienna, Austria phospholipid fatty acid analysis. Abandonment altered floristic composition by replacing shade-intolerant or low-growing grassland species, in particular character species of the alliance Bromion erecti, with medium- to tall-sized grasses (e.g. Brachypodium pinnatum) and tall herbs (e.g. Laserpitium latifolium). Time since abandonment had an influence on the magnitude of successional changes after abandonment. Cessation of mowing increased above-ground phytomass but decreased plant species richness and evenness. Abandonment increased soil microbial biomass, promoted litter decomposition and led to an increased soil organic carbon, $\mathrm{C}: \mathrm{N}$ ratio, and inorganic $\mathrm{N}$ supply. Our findings also showed that abandoned grasslands dominated by grasses remained shrub- and treeless for several decades.

Keywords mountain grasslands · grassland ecology · plant ecology $\cdot$ biodiversity $\cdot$ agroecosystems $\cdot$ soil ecology $\cdot$ agricultural management $\cdot$ abandonment

\section{Introduction}

Mountain regions are worldwide of utmost importance to biodiversity (MacDonald et al. 2000). In the Eastern Alps and in many other European mountain regions, unfavourable topographical and climatic conditions preclude an intensive agricultural land use. Thus, the agricultural landscape is characterized by a high proportion of extensive grasslands. Extensively managed grasslands (one cut each year in mid-summer without organic or inorganic fertilization, no over-sowing or herbicide 
treatment) in the montane and subalpine regions represent low productive, species-rich, semi-natural plagioclimax communities. Especially semi-natural, dry, calcareous grasslands belong to the most speciesrich agroecosystems in Europe, and thus have a great nature conservation value (Poschlod and Wallis De Vries 2002). During the twentieth century, the number and area of this habitat type decreased dramatically due to intensification of grassland management, abandonment, afforestation or conversion to other land-use types. Nowadays, semi-natural calcareous grasslands are threatened throughout Europe (Poschlod and Wallis De Vries 2002). The maintenance of these species-rich grasslands by extensive management is therefore an important conservation target in Europe.

Several studies have investigated the ecological consequences of grassland abandonment (Moog et al. 2002; Niedrist et al. 2009; Walcher et al. 2017; Hussain et al. 2018). However, little information is available on concurrent changes of soil properties (Köhler et al. 2001; Oelmann et al. 2017; Zeller et al. 2001).

From a climate change point of view, information on alterations in litter decomposition and soil organic carbon (SOC) sequestration after abandonment are important because of their feedbacks on climate processes. Also, from an environmental and nature conservation viewpoint, more detailed information on soil and vegetation changes induced by abandonment are desirable because alterations in plant diversity, composition and structure of grassland communities as well as changes in soil physical, chemical and microbiological properties may have long-term consequences for the provision of ecosystem services (ESs).

Litter decomposition in the soil influences build-up of soil organic matter (SOM) and provides the primary source of inorganic $\mathrm{N}$ for plants and soil organisms in seminatural grasslands (Parton et al. 2007). Soil N supply, in turn, plays a major role in determining species composition, plant diversity and productivity of the grassland vegetation, thereby influencing the rate and pattern of successional changes in grassland communities after abandonment (Tilman 1987). Litter decomposition is mainly controlled by microclimate, litter quality and by the diversity, composition and activity of the soil decomposer community (Scherer-Lorenzen 2008). Soil microbial communities are strongly influenced by climate (especially precipitation), vegetation, soil properties and land use (De Vries et al. 2012). Abandonment may alter the size, activity and composition of the soil microbial biomass through vegetation changes (plant biomass production, rhizodeposition, vegetation composition, species dominance, plant diversity) and soil changes ( $\mathrm{pH}, \mathrm{N}$ supply, quantity and quality of SOM, soil temperature and moisture).

For landscape management it is important to know whether the environmental impacts of abandonment are primarily site- or habitat-specific. If semi-natural grasslands from different mountain regions in the Eastern Alps respond to abandonment consistently, we would be able to identify a general successional pattern and to predict the environmental impacts of abandonment more generally. This, in turn, is important for setting priorities in species and habitat conservation as well as for developing general landscape management recommendations.

The objective of this study was to evaluate the ecological responses of semi-natural grasslands to abandonment in different mountain regions in the Eastern Alps. We hypothesized that abandonment leads to consistent changes of vegetation, soil and microbial properties within the same habitat type under different climatic conditions, which in turn influences major ecosystem processes (plant biomass production, litter decomposition, SOC sequestration, $\mathrm{N}$ cycling) in a similar vein. We focused on extensively managed grasslands on semi-dry, nutrientpoor, base-rich soils because this habitat type is threatened throughout Europe by land-use change.

\section{Material and methods}

Study regions and study sites

The study was conducted in three mountain regions (Val Müstair, Central Ennstal, Great Walsertal) in the Swiss and Austrian Alps representing low-, intermediate- and high-rainfall areas, respectively (Fig. 1, Table 1). Within each study region, we compared long-term ( $>30$ years) extensively managed grasslands with immediately neighbouring abandoned grasslands. Altogether, we surveyed ten regularly managed (mown) and ten abandoned (unmown) grasslands at various sites in different regions. At each study site, managed and adjacent abandoned grasslands did not differ in their abiotic site conditions (topography, bedrock, soil type, soil thickness). The study sites were particularly suited for this 'paired-site' study because they enabled the use of chronosequences (space-for-time substitution) to study the long-term ecological consequences of grassland abandonment (Walker et al. 2010). 
Fig. 1 Location of the study regions in the Swiss and Austrian Alps

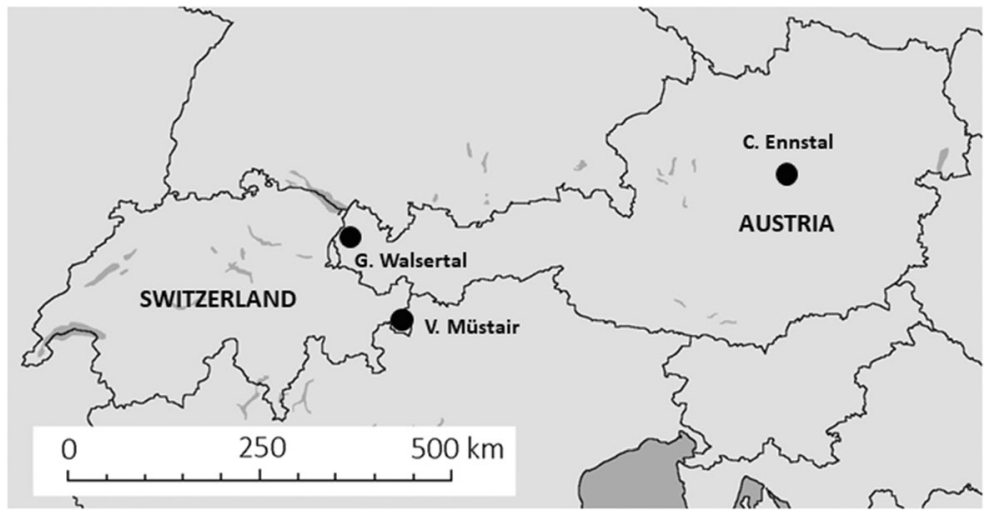

The study sites were located in the montane and subalpine belt on south-facing slopes. Altitude varied from 660 to $1,800 \mathrm{~m}$ a.s.l. (Table 1). Soil types were nutrient-poor, well-aerated Rendzinas and calcic Cambisols developed over limestone or marl with mull humus and a loose, porous crumb structure in topsoil. Thickness of A horizon varied from 20 to $90 \mathrm{~cm}$. The managed grasslands were mown once a year, usually between mid-July and the beginning of August, and received neither farmyard manure nor mineral fertilizers. None of the traditionally managed grassland sites was grazed, re-seeded or irrigated. Before cessation of mowing, the abandoned grasslands were also used as extensively managed grasslands. Therefore, we assume that the initial plant species composition, species richness, soil properties and soil microbial community composition of both land-use types were similar. The time elapsed since abandonment varied from 15 to 60 years. During the successional time, there was no human-mediated disturbance at the studied abandoned grassland sites. However, localized natural biotic disturbance through the activity of small rodents (e.g. voles) or browsing by wild animals (e.g. deer) cannot be ruled out. Phytosociologically, the managed grasslands belonged to the alliance Bromion erecti, which is widely distributed throughout Europe (Mucina et al. 2016; Willner et al. 2019). The plant communities within this alliance are characterized by a restricted water and nutrient supply (lack of plant available nitrogen and phosphorus), low productivity and high vascular plant

Table 1 Characteristics of the study regions and study sites

\begin{tabular}{llll}
\hline $\begin{array}{l}\text { Environmental variables and management } \\
\text { history }\end{array}$ & $\begin{array}{l}\text { G. Walsertal (Vorarlberg, } \\
\text { Austria) }\end{array}$ & $\begin{array}{l}\text { V. Müstair (Graubünden, } \\
\text { Switzerland) }\end{array}$ & $\begin{array}{l}\text { C. Ennstal (Styria, } \\
\text { Austria) }\end{array}$ \\
\hline $\begin{array}{l}\text { Geographic location } \\
\text { of the study sites }\end{array}$ & $\begin{array}{l}47^{\circ} 14^{\prime}-47^{\circ} 15^{\prime} \mathrm{N} \\
9^{\circ} 57^{\prime}-9^{\circ} 58^{\prime} \mathrm{E}\end{array}$ & $\begin{array}{l}46^{\circ} 36^{\prime}-46^{\circ} 37^{\prime} \mathrm{N} \\
10^{\circ} 21^{\prime}-10^{\circ} 25^{\prime} \mathrm{E}\end{array}$ & $\begin{array}{c}47^{\circ} 31^{\prime}-47^{\circ} 40^{\prime} \mathrm{N} \\
14^{\circ} 04^{\prime}-14^{\circ} 35^{\prime} \mathrm{E}\end{array}$ \\
$\begin{array}{l}\text { Number of study } \\
\text { sites }\end{array}$ & 3 & 3 & 4 \\
$\begin{array}{l}\text { Years since } \\
\text { abandonment }\end{array}$ & $35-60$ & $15-20$ & $20-40$ \\
$\begin{array}{l}\text { Altitude of the study sites [m a.s.1.] } \\
\left.\text { Mean annual air temperature [ }{ }^{\circ} \mathrm{C}\right]\end{array}$ & $1,180-1,250$ & $1,740-1,800$ & $660-790$ \\
$\begin{array}{l}\text { Mean air temperature } \\
\text { January [ }{ }^{\circ} \mathrm{C} \text { ] }\end{array}$ & +5.7 & +5.9 & +6.9 \\
Mean air temperature & -2.4 & 16 & -3.9 \\
$\begin{array}{l}\text { July [ }{ }^{\circ} \mathrm{C} \text { ] } \\
\text { Mean annual precipitation }[\mathrm{mm}]\end{array}$ & 1,637 & 811 & 17 \\
\hline
\end{tabular}


species richness (Köhler et al. 2001). The abandoned grasslands represented plant communities in a successional stage characterized by the dominance of tall grasses (Brachypodium pinnatum stage). The surrounding vegetation of the study sites were forests, hedgerows, shrub communities and more intensively managed permanent meadows.

Vegetation survey and phytomass harvest

Vegetation surveys were carried out in June 2015. At each site an area was selected which was fairly uniform with respect to topography, soil type and vegetation. Within this area, four plots $(1 \times 1 \mathrm{~m})$, each spaced $5 \mathrm{~m}$ apart, were placed side by side (Fig. 2). The choice of the plot size $\left(1 \mathrm{~m}^{2}\right)$ for the measurement of vegetation characteristics was governed by the need to compare our results with data from literature. To avoid edge effects, at each study site the spatial distance between managed and abandoned plots was at least $20 \mathrm{~m}$. Vegetation surveys were carried out with a modified Braun-
Blanquet scale for species cover consisting of three subdivisions per cover class (Supplementary Table S1; Braun-Blanquet 1964). Only vascular plant species were recorded. Taxonomy and nomenclature follows Fischer et al. (2008). All plots were revisited in August 2015 to ensure that late-flowering species had not been missed. For vegetation analyses, means of the minimum and maximum of modified Braun-Blanquet cover-classranges were used.

To assess vegetation changes due to abandonment, the following plant parameters were analysed (i) total vegetation cover, cover of plant functional groups (grasses, herbs, legumes) and individual cover of all vascular plant species; (ii) species richness (number of species per plot), Shannon index and evenness; (iii) flower traits (colour, abundance, cover); (iv) plant strategy types according to (Grime 1977) and four plant traits (life span, type of reproduction, Raunkicer life form, type of rosettes, unweighted in each case); (v) unweighted Ellenberg indicator values for light, soil moisture and nutrient availability (Ellenberg et al. 2001).

\section{abandoned meadow}

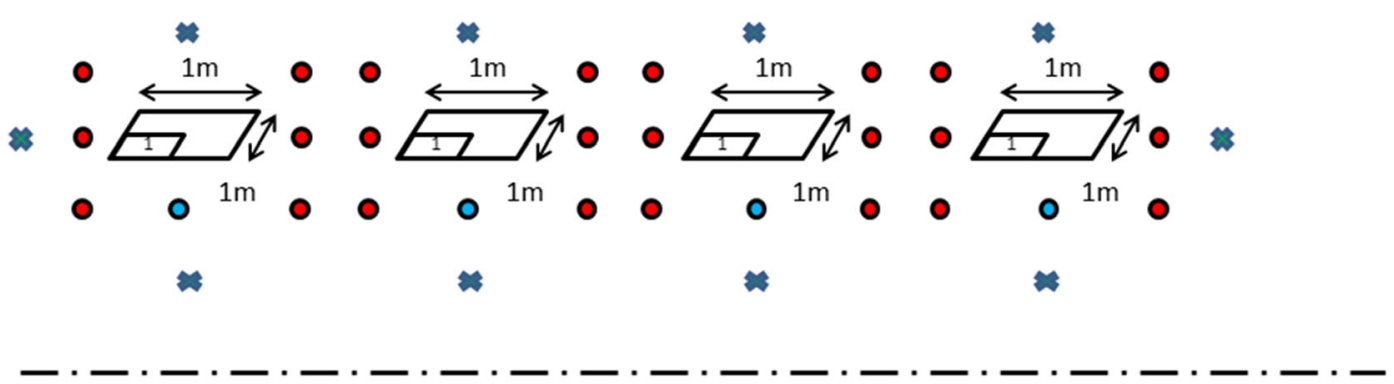

managed meadow

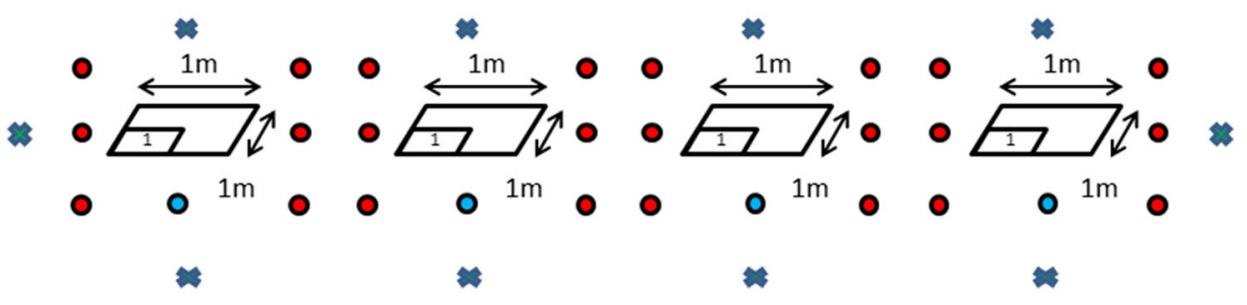

1 ... phytomass harvest $\left(0,25 \mathrm{~m}^{2}\right)$ ... soil samples $\$$... tea bags ...soil water content and soil temperature

Fig. 2 Schematic overview of the study and sampling design 
Total vegetation cover, flower cover and cover of plant functional groups were recorded as percentage cover per $\mathrm{m}^{2}$. The flower cover was estimated both in June and August 2015, reflecting different phenological stages of the plant community. Plant traits were selected based on field experience and from information in the literature (Prévosto et al. 2011). Plant strategy types, plant traits and flower colour were abstracted from the BIOLFLOR database (Klotz et al. 2002). Both plant traits and Ellenberg indicator values were not weighted by abundance because in species-rich vegetation types weighted and unweighted averages usually give similar results (Diekmann 2003).

Standing phytomass was assessed on a $50 \times 50 \mathrm{~cm}$ area of each plot in June 2015 (Fig. 2). The plants were clipped by hand shears at the soil surface. The harvested phytomass was sorted into five categories: grasses, herbs, legumes, necromass and biomass. In this study, we distinguished between biomass (living green plant tissue), necromass (dead tissue on the plant), phytomass (biomass plus necromass) and plant litter (dead plant material at the soil surface). Plant samples were dried at $60^{\circ} \mathrm{C}$ for $72 \mathrm{~h}$.

\section{Soil sampling and soil analysis}

At each study site, six individual soil samples were taken randomly outside of each vegetation plot at a distance of $1 \mathrm{~m}$ with a soil corer ( $4 \mathrm{~cm}$ diameter). Soil sampling was performed in June and August 2015 from the main rooting zone of the plants $(0-10 \mathrm{~cm}$ depth). Samples were mixed to obtain one composite sample per site and sampling date (Fig. 2). We only sampled the uppermost $10 \mathrm{~cm}$ of the soil because this soil layer responds most sensitively to changes in grassland management (Bohner et al. 2016). Soil samples were transported to the laboratory in cool boxes and stored at $-20^{\circ} \mathrm{C}$ until analyses. An aliquot of each sample was air-dried and passed through a 2-mm sieve for the analysis of basic soil parameters. Total carbon $\left(\mathrm{C}_{\mathrm{tot}}\right)$ and total nitrogen $\left(\mathrm{N}_{\text {tot }}\right)$ were determined by dry combustion $\left(1,250^{\circ} \mathrm{C}\right)$ using an elemental analyser (LECO TruMac, LECO Corp., St. Joseph, USA). Carbonate was measured gas-volumetrically. Organic carbon $\left(\mathrm{C}_{\mathrm{org}}\right)$ was calculated as the difference between total $\mathrm{C}$ and carbonate $\mathrm{C}$. Soil $\mathrm{pH}$ was measured in $0.01 \mathrm{M} \mathrm{CaCl}_{2}$ solution at a soil-to-solution ratio of 1:2.5 using a glass electrode. $\mathrm{NH}_{4}-\mathrm{N}$ and $\mathrm{NO}_{3}-\mathrm{N}$ were determined colourimetrically after extraction with $1 \mathrm{M} \mathrm{KCl}$ (Hood-Nowotny et al. 2010). Soil microbial community composition was assessed in June and August 2015 by analysing the microbial phospholipid fatty acid (PLFA) composition (Hackl et al. 2005). Therefore, soil (1.5 g fresh weight) was extracted with a buffer mixture consisting of chloroform:methanol:citrate buffer (1:2:0.8, v/v/v). The lipids were separated into neutral lipids, glycolipids and phospholipids on a silicic acid column. After a mild alkaline methanolysis the phospholipid methyl esters were separated on an Agilent 6890 gas chromatograph equipped with a flame ionization detector (Agilent Inc., Santa Clara, CA, USA). Methyl non-adecanoate fatty acid (19:0) was added as internal standard in order to quantify peak areas. A standard qualitative bacterial acid methyl esters mix (BAC mix) and a standard qualitative fatty acid methyl esters mix (FAME mix; both Sigma Aldrich Co., St. Louis, MO) were also measured to allow identification of the fatty acid peaks. In total, 31 PLFAs were identified. The total amount of PLFAs was used as a measure of the active soil microbial biomass (Zeller et al. 2001).

At each study site, in June and August 2015 gravimetric soil water content was determined using four soil cores $(0-10 \mathrm{~cm}$ depth, diameter $4 \mathrm{~cm})$ and soil temperature was measured in $5 \mathrm{~cm}$ depth using four insertion thermometers (Voltcraft DET3R, Conrad Electronic SE, Hirschau, Germany). The measurements were taken outside of the vegetation plots at a distance of $1 \mathrm{~m}$ (Fig. 2).

\section{Litter decomposition}

Litter decomposition was determined using the 'tea bag index' (TBI; Keuskamp et al. 2013). The TBI consists of two parameters: litter decomposition rate $(\mathrm{k})$ expresses the velocity of decomposition, while litter stabilization factor (S) expresses the inhibiting effect of environmental conditions on the decomposition. Both parameters are based on weight loss of litter material. Two tea types with contrasting decomposition characteristics were used: green tea (Camellia sinensis; Lipton, EAN 87 22700055525 ) with high cellulose content and expected fast decomposition and rooibos tea (Aspalathus linearis; Lipton, EAN 872270018843 8) with high lignin content and expected slow decomposition (Keuskamp et al. 2013). At each study site, ten pairs of green and rooibos tea bags were buried in June 2015 in 
$8 \mathrm{~cm}$ soil depth outside of the vegetation plots at a distance of $1 \mathrm{~m}$ (Fig. 2). The tea bags were retrieved after a field incubation period of 52 and 79 days. The tea bags were cleaned from adhered soil particles and roots, dried at $70^{\circ} \mathrm{C}$ for $48 \mathrm{~h}$ and weighed. Stabilization factor $\mathrm{S}$ and decomposition rate $\mathrm{k}$ were calculated using the hydrolysable fraction of green tea $\left(0.842 \mathrm{~g} \cdot \mathrm{g}^{-1}\right)$ and rooibos tea $\left(0.552 \mathrm{~g} \cdot \mathrm{g}^{-1}\right)$.

\section{Statistical analysis}

Normal distribution of residuals was checked with qqplots and Shapiro-Wilk tests, homogeneity of variances with histograms and Bartlett-tests. When assumptions were met, we performed analyses of variances (ANOVAs) with management, sampling date and region (block) as factors. When sampling date was not significantly different, means between the two sampling dates were analysed. If assumptions for parametric statistics were not met we applied Box-Cox transformations or performed non-parametric Kruskal-Wallis tests. For post-hoc comparisons of ANOVAs, we used Tukey tests. Correlations were tested with Pearson's correlation coefficient. Differences in plant species composition were analysed by principal coordinate analyses (PCO) using PerMANOVA by applying a Bray-Curtis distance matrix and 9,999 permutations. The assumption of homogeneity of multivariate dispersions among treatments for PerMANOVA was checked. PerMANOVA was carried out with Primer (Primer6 and Permanova+ 2003), all other statistical analyses with $\mathrm{R}$ (version 3.1.1; R Development Core Team 2014). All results were stated as statistically significant if $P<0.05$.

\section{Results}

Vegetation characteristics

In all study regions, mean species richness, ShannonIndex and evenness were significantly lower on abandoned than on managed plots (Tables 2 and 3). Across study regions, species composition of the vegetation was significantly affected by abandonment. Abandoned plots were clearly separated from managed plots by the first axis in the PCO-plot (Fig. 3). In each study region, vegetation composition differed considerably between
Table 2 ANOVA and Kruskal-Wallis results for the effects of management and region on vegetation characteristics

\begin{tabular}{|c|c|c|c|}
\hline \multirow[t]{2}{*}{ Parameter } & Treatment & Region & $\begin{array}{l}\text { Treatment } \times \\
\text { region }\end{array}$ \\
\hline & $F_{1,78}$ & $F_{2,77}$ & $F_{2,77}$ \\
\hline Total vegetation cover & $41.921 *$ & $39.440 *$ & $6.846^{*}$ \\
\hline Ag phytomass & $25.451 *$ & $5.807 *$ & 2.242 \\
\hline Ag plant biomass & $5.054 *$ & $18.099 *$ & 1.241 \\
\hline Necromass & $34.853 *$ & 2.631 & \\
\hline Species richness & $135.320 *$ & $12.962 *$ & $3.196^{*}$ \\
\hline Shannon-Index & $84.779 *$ & 1.621 & $3.456^{*}$ \\
\hline Evenness & $56.534 *$ & 0.580 & $5.575^{*}$ \\
\hline EIV1 & $40.322 *$ & 1.994 & 1.722 \\
\hline EIVm & $5.714 *$ & 1.978 & 0.437 \\
\hline EIVn & 0.408 & $7.306^{*}$ & $6.169^{*}$ \\
\hline Legumes & $27.984 *$ & $4.974 *$ & $8.107 *$ \\
\hline Herbs & $13.670^{*}$ & $6.190 *$ & $4.340^{*}$ \\
\hline Grasses & 0.055 & $4.812 *$ & 0.492 \\
\hline
\end{tabular}

*After values refer to significant differences $(P<0.05)$. Ag Above-ground, EIV1 - Ellenberg light indicator, EIVm Ellenberg soil moisture indicator, EIVn - Ellenberg nutrient availability indicator

abandoned and managed plots but was quite similar within the abandoned and managed plots (Fig. 3).

The dominant species in managed plots was Bromus erectus. In abandoned plots, however, Brachypodium pinnatum was dominant (Supplementary Table S2). Most of the plant species in abandoned plots were common and widespread species whereas character species of the alliance Bromion erecti were scarce. Only a few species were restricted to abandoned plots (Trifolium medium, Vicia sepium, Cephalanthera damasonium, Epipactis atrorubens, Galeopsis tetrahit, Anthericum ramosum, Lilium bulbiferum subsp. bulbiferum, Hypericum perforatum, Rubus idaeus, Rosa species). Most of them are usually found in forests, forest edges and forest clearings. In abandoned plots, seedlings of Fraxinus excelsior were the most abundant woody plants (cover: always less than $0.5 \%$, frequency: $15 \%$ ).

Managed plots were dominated by light-demanding and drought-tolerant, low soil fertility grassland species. The mean Ellenberg indicator value for light was significantly lower on abandoned than on managed plots whereas that for soil moisture was significantly higher. The mean Ellenberg indicator value for nutrient availability, however, showed no consistent trend in response to abandonment (Tables 2 and 3). 
Table 3 Vegetation parameter of the managed and abandoned grasslands under study

\begin{tabular}{|c|c|c|c|}
\hline Parameter & Region & $\begin{array}{l}\text { Managed } \\
\text { grasslands }\end{array}$ & Abandoned \\
\hline \multirow[t]{3}{*}{ Total vegetation cover $[\%]$} & G. Walsertal & $98.3 \pm 1.3$ & $99.0 \pm 0.0$ \\
\hline & V. Müstair & $97.1 \pm 1.9$ & $99.4 \pm 0.5$ \\
\hline & C. Ennstal & $92.6 \pm 6.8$ & $97.8 \pm 1.4$ \\
\hline \multirow{3}{*}{$\begin{array}{l}\text { Above-ground } \\
\text { phytomass }\left[\mathrm{g} \cdot \mathrm{m}^{-2} \cdot \mathrm{DM}\right]\end{array}$} & G. Walsertal & $391.8 \pm 138.3$ & $559.8 \pm 116.0$ \\
\hline & V. Müstair & $298.1 \pm 81.1$ & $428.5 \pm 219.0^{*}$ \\
\hline & C. Ennstal & $520.5 \pm 115.2$ & $560.4 \pm 112.8^{*}$ \\
\hline \multirow{3}{*}{$\begin{array}{l}\text { Above-ground plant } \\
\text { biomass }\left[\mathrm{g} \cdot \mathrm{m}^{-2} \cdot \mathrm{DM}\right)\end{array}$} & G. Walsertal & $258.2 \pm 57.9$ & $266.2 \pm 61.6$ \\
\hline & V. Müstair & $143.4 \pm 40.4$ & $166.6 \pm 83.6$ \\
\hline & C. Ennstal & $189.9 \pm 66.8$ & $248.1 \pm 63.6^{*}$ \\
\hline \multirow[t]{3}{*}{ Necromass $\left(\mathrm{g} \cdot \mathrm{m}^{-2} \cdot \mathrm{DM}\right)$} & G. Walsertal & $4.1 \pm 2.3$ & $27.9 \pm 35.7 *$ \\
\hline & V. Müstair & $2.3 \pm 2.8$ & $95.4 \pm 78.6^{*}$ \\
\hline & C. Ennstal & $12.0 \pm 21.2$ & $63.5 \pm 55.5^{*}$ \\
\hline \multirow[t]{3}{*}{ Species richness } & G. Walsertal & $30.8 \pm 3.6$ & $13.7 \pm 2.4^{*}$ \\
\hline & V. Müstair & $25.0 \pm 5.1$ & $12.6 \pm 3.1^{*}$ \\
\hline & C. Ennstal & $31.3 \pm 7.1$ & $20.3 \pm 6.1^{*}$ \\
\hline \multirow[t]{3}{*}{ Shannon index } & G. Walsertal & $2.21 \pm 0.2$ & $1.38 \pm 0.2 *$ \\
\hline & V. Müstair & $2.48 \pm 0.2$ & $1.11 \pm 0.4^{*}$ \\
\hline & C. Ennstal & $2.46 \pm 0.6$ & $1.51 \pm 0.5^{*}$ \\
\hline \multirow[t]{3}{*}{ Evenness } & G. Walsertal & $64 \pm 0.1$ & $53 \pm 0.1 *$ \\
\hline & V. Müstair & $78 \pm 0.1$ & $44 \pm 0.2 *$ \\
\hline & C. Ennstal & $72 \pm 0.1$ & $50 \pm 0.1 *$ \\
\hline \multirow[t]{3}{*}{ Ellenberg light indicator } & G. Walsertal & $7.2 \pm 0.2$ & $6.7 \pm 0.2 *$ \\
\hline & V. Müstair & $7.2 \pm 0.1$ & $6.8 \pm 0.5^{*}$ \\
\hline & C. Ennstal & $7.1 \pm 0.2$ & $6.8 \pm 0.2^{*}$ \\
\hline Ellenberg soil moisture & G. Walsertal & $4.1 \pm 0.2$ & $4.4 \pm 0.4 *$ \\
\hline \multirow[t]{2}{*}{ indicator } & V. Müstair & $4.1 \pm 0.2$ & $4.2 \pm 0.4$ \\
\hline & C. Ennstal & $4.3 \pm 0.5$ & $4.4 \pm 0.4$ \\
\hline Ellenberg nutrient & G. Walsertal & $3.7 \pm 0.3$ & $3.1 \pm 0.3^{*}$ \\
\hline \multirow[t]{2}{*}{ availability indicator } & V. Müstair & $3.1 \pm 0.4$ & $3.6 \pm 0.8$ \\
\hline & C. Ennstal & $4.0 \pm 0.8$ & $4.0 \pm 0.9$ \\
\hline
\end{tabular}

*After values refer to significant differences within a region $(P<0.05)$. Means $\pm S D, n=3$ for G. Walsertal and V. Müstair, $n=4$ for C. Ennstal, DM - dry mass

Grasses were the dominant functional group across all sites. The proportion of both herbs and legumes was significantly lower on abandoned than on managed plots (Table 4). Vegetation on all plots was dominated by perennials which accounted for more than $90 \%$ of the total vegetation cover. Proportion of perennials was significantly higher on abandoned than on managed plots, while that of biennials was significantly lower. Proportion of species reproducing by seeds only was significantly lower on abandoned than on managed plots. Proportion of hemicryptophytes was significantly lower and that of chamaephytes was slightly lower on abandoned than on managed plots, while the proportion of both geophytes and phanerophytes was comparatively higher; proportion of therophytes was similar in both land-use types. Proportion of erosulate plants was significantly higher on abandoned than on managed plots, while that of hemirosette plants was significantly lower. Proportion of competitors was significantly higher on abandoned plots compared to managed plots whereas that of ruderals was significantly lower. Proportion of stress-tolerators was unaffected. 
Plant species composition
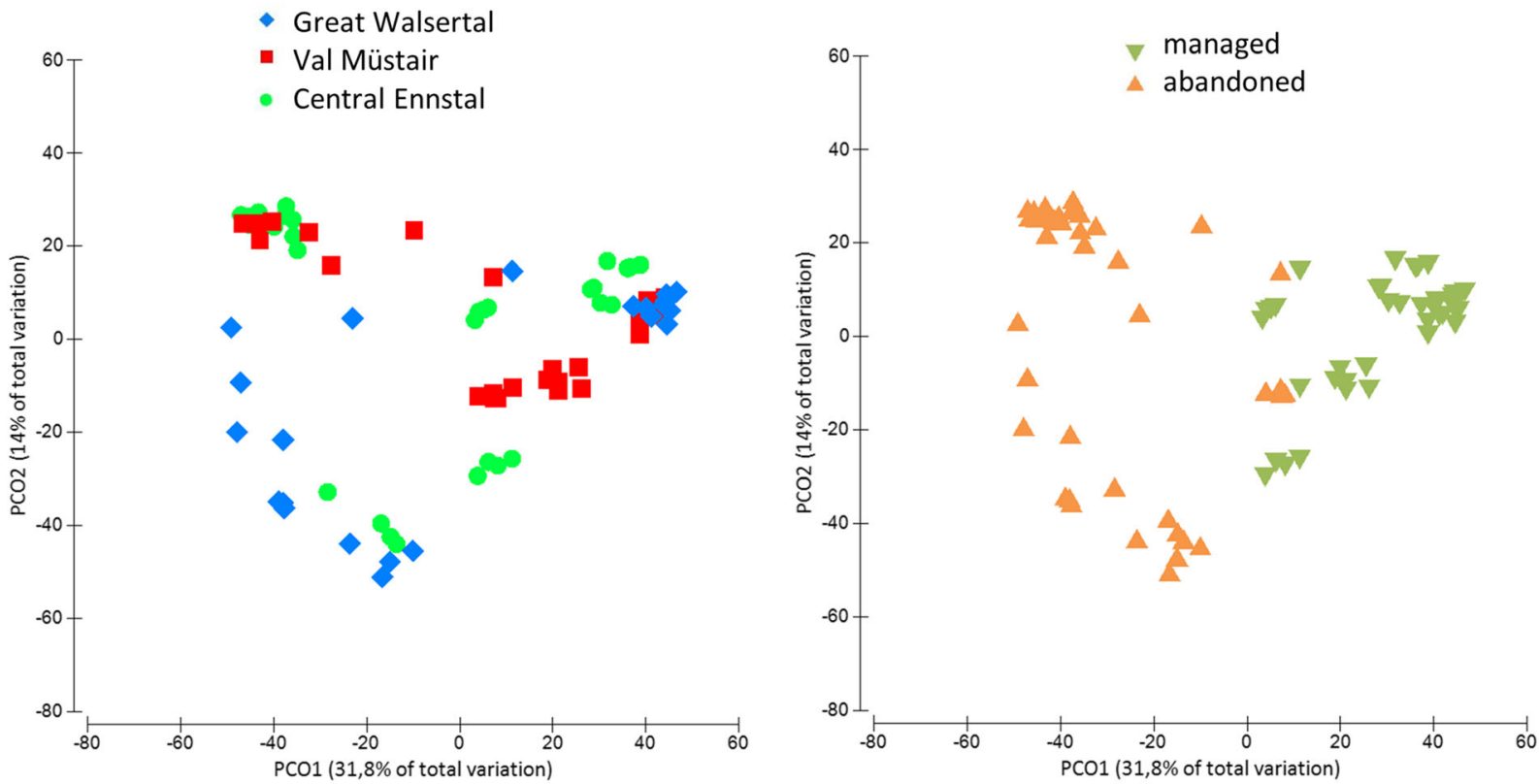

Great Walsertal

Val Müstair
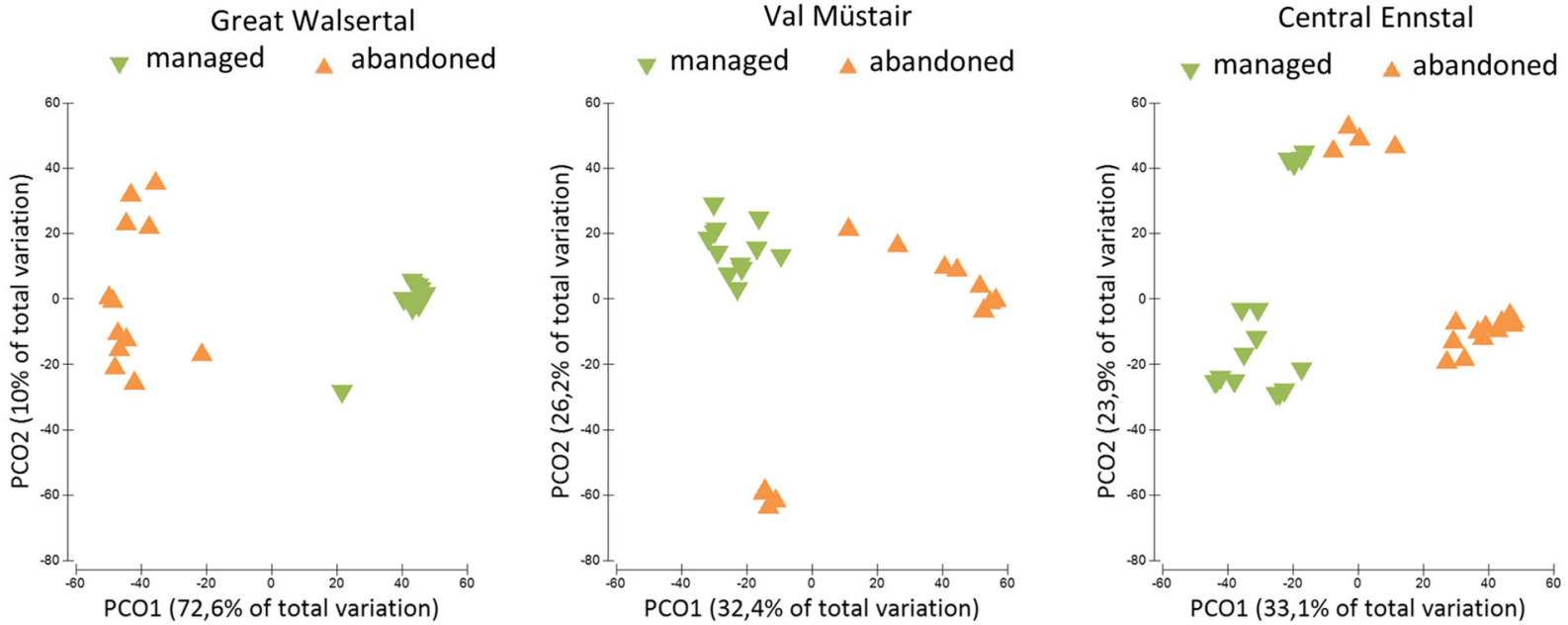

Fig. 3 Principal coordinate analysis (PCO) showing plant species composition in managed and abandoned grasslands in three different regions in the Eastern Alps. $n=3$ for G. Walsertal and V. Müstair, $n=4$ for C. Ennstal

At peak season, total vegetation cover, aboveground phytomass, above-ground plant biomass and necromass were significantly higher on abandoned than on managed plots (Table 2). Biomass to necromass ratios varied from 2 to 10 in abandoned and from 16 to 63 in managed plots. In both landuse types, the necromass was mainly composed of dead grass leaves, which were concentrated in the lower canopy layer.
At peak flowering season in June, the percentage of flowering species and the flower cover were significantly lower on abandoned than on managed plots whereas in August after mowing both parameters were comparatively higher, though not significantly, on abandoned plots (Table 4). In both land-use types, the prevalent flower colours of blooming plants were yellow and white. On managed plots, the flower colours were more evenly distributed than on abandoned plots. 
Table 4 Vegetation parameter of the managed and abandoned grasslands under study

\begin{tabular}{|c|c|c|}
\hline Parameter & $\begin{array}{l}\text { Managed } \\
\text { grasslands }\end{array}$ & Abandoned \\
\hline \multicolumn{3}{|l|}{ Plant functional groups } \\
\hline Grasses [\%] & 64 & 76 \\
\hline Herbs $[\%]$ & 28 & $21 *$ \\
\hline Legumes $[\%]$ & 8 & $3 *$ \\
\hline \multicolumn{3}{|l|}{ Life span } \\
\hline Annual [\%] & 3.8 & 3.1 \\
\hline Biennial $[\%]$ & 3.7 & $0.5^{*}$ \\
\hline Perennial $[\%]$ & 92.5 & $96.4^{*}$ \\
\hline \multicolumn{3}{|l|}{ Type of reproduction } \\
\hline Only by seed [\%] & 24.8 & $17.4^{*}$ \\
\hline Mostly by seed, rarely vegetatively [\%] & 23.0 & 24.6 \\
\hline By seed and vegetatively [\%] & 50.4 & 53.9 \\
\hline Mostly vegetatively, rarely by seed [\%] & 1.8 & 4.1 \\
\hline \multicolumn{3}{|l|}{ Raunkiaer life form } \\
\hline Therophytes [\%] & 3.3 & 3.2 \\
\hline Hemicryptophytes [\%] & 83.2 & $77.9^{*}$ \\
\hline Geophytes [\%] & 5.1 & 8.2 \\
\hline Chamaephytes [\%] & 4.2 & 3.0 \\
\hline Phanerophytes [\%] & 4.2 & 7.7 \\
\hline \multicolumn{3}{|l|}{ Type of rosettes } \\
\hline Erosulate plant [\%] & 24.9 & $36.8 *$ \\
\hline Hemirosette plant [\%] & 63.6 & $53.0 *$ \\
\hline Rosette plant [\%] & 11.5 & 10.2 \\
\hline \multicolumn{3}{|l|}{ Plant strategy types } \\
\hline Competitors $[\%]$ & 53 & $60 *$ \\
\hline Stress-tolerators [\%] & 26 & 26 \\
\hline Ruderals [\%] & 21 & $14 *$ \\
\hline \multicolumn{3}{|l|}{ Flower colour (flowering plants) } \\
\hline Blue $[\%]$ & 10.5 & $2.5^{*}$ \\
\hline Brown $[\%]$ & 1.2 & 0.8 \\
\hline Yellow [\%] & 35.8 & 48.2 \\
\hline Green $[\%]$ & 2.8 & $1.6^{*}$ \\
\hline $\operatorname{Red}[\%]$ & 17.6 & $16.3^{*}$ \\
\hline White $[\%]$ & 32.1 & 30.6 \\
\hline \multicolumn{3}{|l|}{ Flower abundance (June) } \\
\hline Flowering species [\%] & 30.7 & $17.7 *$ \\
\hline Flower cover $[\%]$ & 3.85 & $0.80 *$ \\
\hline \multicolumn{3}{|l|}{ Flower abundance (August) } \\
\hline Flowering species [\%] & 3.6 & 7.1 \\
\hline Flower cover $[\%]$ & 0.28 & 0.29 \\
\hline
\end{tabular}

*After values refer to significant differences $(P<0.05)$
Topsoil properties

Across study regions, both the concentration of $\mathrm{C}_{\text {org }}$ and the $\mathrm{C}: \mathrm{N}$ ratio in topsoil were significantly higher on abandoned than on managed plots (Table 5). The soil organic C (SOC) accumulation as a result of abandonment was associated with $\mathrm{N}_{\text {tot }}$ enrichment in all study regions, except V. Müstair. At the sampling date in June, the $\mathrm{NH}_{4}-\mathrm{N}$ concentration in topsoil was significantly higher on abandoned plots compared to managed plots (Table 5). In the uppermost soil layer of both land-use types, the concentration of $\mathrm{NO}_{3}-\mathrm{N}$ was significantly lower than that of $\mathrm{NH}_{4}-\mathrm{N}$. The topsoils $(0-10 \mathrm{~cm}$ depth) of both land-use types were in the carbonate buffer range $\left(\mathrm{pH} \mathrm{CaCl}_{2}:>\right.$ 6.2; Table 6). Soil temperature in $5 \mathrm{~cm}$ depth at the two sampling dates in June and August 2015 was significantly lower on abandoned than on managed plots in V. Müstair and C. Ennstal (Table 6). In all study regions, except V. Müstair, soil moisture in the layer $0-10 \mathrm{~cm}$ tended to be higher in abandoned than in managed plots.

Soil microbial community composition varied considerably among study regions. The total amount of PLFAs and the relative proportions of the functional groups of soil microorganisms revealed no significant differences between managed and abandoned plots (Table 5). In all study regions, the soil microbial community was dominated by bacteria (Supplementary Table S3). Generally, gramnegative bacteria represented the largest proportion of total PLFAs. In each study region, the proportions of gram-positive bacteria, gram-negative bacteria and arbuscular mycorrhizal fungi (AMF) were slightly higher in abandoned than in managed plots. For other functional groups, no consistent trend was observed. The ratio of gram-positive to gramnegative bacteria was only slightly affected by abandonment. The ratio of bacterial to fungal PLFA was higher, though not significantly, in abandoned than in managed plots. The total amount of PLFAs correlated positively with concentrations of $\mathrm{C}_{\text {org }}$ $\left(\rho_{\text {sumplfa, Corg }}=0.900, P<0.001\right), \mathrm{N}_{\text {tot }}$ ( $\left.\rho_{\text {sumPLFA,Ntot }}=0.887, \mathrm{P}<0.001\right), \mathrm{NH}_{4}-\mathrm{N}$ in August $\left(\rho_{\text {sumPLFA,NH4-N }}=0.789, P<0.001\right), \mathrm{NO}_{3}-\mathrm{N}$ in August $\left(\rho_{\text {sumPLFA,NO3-N }}=0.663, \mathrm{P}=0.003\right)$ and soil moisture $\left(\rho_{\text {sumPLFA,moisture }}=0.805, P<0.001\right)$. 
Table 5 ANOVA results for the effects of management and region on soil physical and chemical parameters, soil microbial community composition and litter decomposition

\begin{tabular}{|c|c|c|c|}
\hline Parameter & $\begin{array}{l}\text { Treatment } \\
F\end{array}$ & $\begin{array}{l}\text { Region } \\
F\end{array}$ & $\begin{array}{l}\text { Treatment } \times \text { Region } \\
F\end{array}$ \\
\hline \multicolumn{4}{|l|}{ Soil physical and chemical parameters ${ }^{1}$} \\
\hline Soil temperature $\left[{ }^{\circ} \mathrm{C}\right]$ & $22.870 *$ & $52.230^{*}$ & 1.800 \\
\hline Soil moisture [\% of pore volume] & 1.921 & $46.711 *$ & 2.405 \\
\hline $\mathrm{pH}\left(\mathrm{CaCl}_{2}\right)$ & 1.236 & 1.859 & 0.794 \\
\hline $\mathrm{C}_{\text {org }}\left[\mathrm{g} \mathrm{kg}^{-1}\right]$ & $7.922 *$ & $23.394^{*}$ & 2.103 \\
\hline $\mathrm{N}_{\text {tot }}\left[\mathrm{g} \mathrm{kg}^{-1}\right]$ & 1.963 & $27.333^{*}$ & 1.733 \\
\hline $\mathrm{C}: \mathrm{N}$ ratio & $15.622 *$ & $10.447 *$ & 0.796 \\
\hline $\mathrm{NH}_{4}-\mathrm{N}\left[\mu \mathrm{g} \cdot \mathrm{g}^{-1}\right.$ dry soil $]$ - June & $11.906^{*}$ & 2.805 & 1.181 \\
\hline $\mathrm{NO}_{3}-\mathrm{N}\left[\mu \mathrm{g} \cdot \mathrm{g}^{-1}\right.$ dry soil $]$ - June & 1.238 & 0.670 & 0.090 \\
\hline $\mathrm{NH}_{4}-\mathrm{N}\left[\mu \mathrm{g} \cdot \mathrm{g}^{-1}\right.$ dry soil $]$ - August & 3.135 & $8.504 *$ & 2.329 \\
\hline $\mathrm{NO}_{3}-\mathrm{N}\left[\mu \mathrm{g} \cdot \mathrm{g}^{-1}\right.$ dry soil $]$ - August & 0.002 & $11.828 *$ & 0.435 \\
\hline \multicolumn{4}{|l|}{ Soil microbial community ${ }^{1}$} \\
\hline Total PLFAs $\left[\mathrm{nmol}^{-1} \mathrm{~g}^{-1}\right.$ dry soil] & 3.271 & $19.596^{*}$ & 0.183 \\
\hline $\mathrm{Gram}^{+}$bacteria $[\%]$ & 0.526 & $12.375^{*}$ & 0.010 \\
\hline $\mathrm{Gram}^{-}$bacteria $[\%]$ & 0.270 & 2.419 & 0.158 \\
\hline Fungi [\%] & 0.094 & $25.780 *$ & 1.243 \\
\hline Arbuscular mycorrhizal fungi [\%] & 0.544 & $12.848^{*}$ & 0.044 \\
\hline Actinomycetes $[\%]$ & 0.016 & $15.356^{*}$ & 0.522 \\
\hline Unspecific bacteria $[\%]$ & 0.003 & $4.207^{*}$ & 0.002 \\
\hline Protozoa $[\%]$ & 0.007 & $9.793 *$ & 0.004 \\
\hline Others $[\%]$ & 3.716 & $50.242 *$ & 0.451 \\
\hline Bacteria:fungi ratio & 1.005 & $30.520 *$ & 0.126 \\
\hline \multicolumn{4}{|l|}{ Litter decomposition $^{2}$} \\
\hline Litter decomposition rate $k$ & $51.042 *$ & $18.128 *$ & $6.453^{*}$ \\
\hline Stabilization factor $S$ & $42.841 *$ & $141.984 *$ & $7.371 *$ \\
\hline
\end{tabular}

*After values refer to significant differences $(P<0.05) .{ }^{1}:$ d.f. treatment: 1,16 ; region: $2,15 .{ }^{2}:$ d.f. treatment: 1,$190 ;$ region: 2,189

Litter decomposition

Across study regions, litter decomposition rate and stabilization factor were significantly higher on abandoned than on managed plots. Both parameters varied considerably among study regions, being highest at the subalpine site V. Müstair (Table 5, Fig. 4). Decomposition rate and stabilization factor correlated positively with necromass $\left(\rho_{\mathrm{k}, \text { necromass }}=0.638, P=0.006 ; \rho_{\mathrm{S} \text {, necromass }}=\right.$ $0.521, P=0.030)$. Stabilization factor correlated negatively with $\mathrm{N}_{\text {tot }}$ in the topsoil $\left(\rho_{\mathrm{S}, \mathrm{Ntot}}=-0.537, P=\right.$ 0.022).

\section{Discussion}

Vegetation changes due to abandonment

Abandonment caused a marked decrease in species richness, Shannon-Index and evenness on all study sites, illustrating the importance of regular mowing for the maintenance of high plant species richness in seminatural grasslands (Ryser et al. 1995; Bohner et al. 2012). Our findings also suggested that the similarity in plant species composition between abandoned and adjacent managed grasslands decrease with increasing 
Table 6 Basic soil physical and chemical properties of the studied managed and abandoned grasslands. Mean values from two sampling dates in June and August 2015

\begin{tabular}{|c|c|c|c|}
\hline Parameter & Region & $\begin{array}{l}\text { Managed } \\
\text { grasslands }\end{array}$ & Abandoned \\
\hline \multirow[t]{3}{*}{ Soil temperature $\left[{ }^{\circ} \mathrm{C}\right]^{\mathrm{x}}$} & G. Walsertal & $15.8 \pm 0.7$ & $14.9 \pm 1.0$ \\
\hline & V. Müstair & $13.9 \pm 0.5$ & $11.9 \pm 0.9^{*}$ \\
\hline & C. Ennstal & $20.6 \pm 1.8$ & $16.9 \pm 1.9^{*}$ \\
\hline \multirow[t]{3}{*}{ Soil moisture $[\% \text { of pore volume }]^{\mathrm{x}}$} & G. Walsertal & $80.0 \pm 8.8$ & $83.4 \pm 15.4$ \\
\hline & V. Müstair & $45.5 \pm 4.7$ & $42.5 \pm 7.4$ \\
\hline & C. Ennstal & $29.8 \pm 13.0$ & $43.6 \pm 14.3$ \\
\hline \multirow[t]{3}{*}{$\mathrm{pH}\left[\mathrm{CaCl}_{2}\right]^{\mathrm{x}}$} & G. Walsertal & $6.4 \pm 0.8$ & $7.0 \pm 0.2$ \\
\hline & V. Müstair & $6.4 \pm 1.3$ & $6.3 \pm 0.8$ \\
\hline & C. Ennstal & $6.7 \pm 0.9$ & $7.1 \pm 0.2$ \\
\hline \multirow[t]{3}{*}{$\mathrm{C}_{\text {org }}\left[\mathrm{g} \mathrm{kg}^{-1}\right]^{\mathrm{x}}$} & G. Walsertal & $107.9 \pm 20.2$ & $138.1 \pm 42.1 *$ \\
\hline & V. Müstair & $62.6 \pm 5.0$ & $62.2 \pm 7.9$ \\
\hline & C. Ennstal & $55.2 \pm 21.3$ & $90.7 \pm 22.6^{*}$ \\
\hline \multirow[t]{3}{*}{$\mathrm{N}_{\text {tot }}\left[\mathrm{g} \cdot \mathrm{kg}^{-1}\right]^{\mathrm{x}}$} & G. Walsertal & $10.6 \pm 1.9$ & $11.8 \pm 3.9$ \\
\hline & V. Müstair & $5.2 \pm 0.4$ & $4.5 \pm 0.9$ \\
\hline & C. Ennstal & $5.2 \pm 2.0$ & $7.7 \pm 1.2$ \\
\hline \multirow[t]{3}{*}{$\mathrm{C}: \mathrm{N}$ ratio $^{\mathrm{x}}$} & G. Walsertal & $10.2 \pm 0.2$ & $11.9 \pm 0.8$ \\
\hline & V. Müstair & $12.0 \pm 0.4$ & $14.2 \pm 2.3$ \\
\hline & C. Ennstal & $10.7 \pm 0.4$ & $11.7 \pm 1.3$ \\
\hline \multirow[t]{3}{*}{$\mathrm{NH}_{4}-\mathrm{N}\left[\mu \mathrm{g} \cdot \mathrm{g}^{-1}\right.$ dry soil $]-\mathrm{June}^{\mathrm{y}}$} & G. Walsertal & $15.9 \pm 1.1$ & $24.9 \pm 7.4$ \\
\hline & V. Müstair & $19.9 \pm 5.0$ & $21.5 \pm 1.0$ \\
\hline & C. Ennstal & $13.5 \pm 1.6$ & $20.0 \pm 4.7$ \\
\hline \multirow[t]{3}{*}{$\mathrm{NO}_{3}-\mathrm{N}\left[\mu \mathrm{g} \cdot \mathrm{g}^{-1}\right.$ dry soil $]-\mathrm{June}^{\mathrm{y}}$} & G. Walsertal & $1.3 \pm 0.6$ & $2.1 \pm 1.7$ \\
\hline & V. Müstair & $0.9 \pm 0.5$ & $1.7 \pm 1.6$ \\
\hline & C. Ennstal & $0.6 \pm 0.6$ & $1.2 \pm 0.6$ \\
\hline \multirow{3}{*}{$\begin{array}{l}\mathrm{NH}_{4}-\mathrm{N}\left[\mu \mathrm{g} \cdot \mathrm{g}^{-1} \text { dry }\right. \\
\text { soil] - August }\end{array}$} & G. Walsertal & $39.5 \pm 3.1$ & $44.9 \pm 9.1$ \\
\hline & V. Müstair & $34.8 \pm 3.4$ & $33.0 \pm 4.6$ \\
\hline & C. Ennstal & $26.4 \pm 3.1$ & $35.1 \pm 4.8$ \\
\hline \multirow[t]{3}{*}{$\mathrm{NO}_{3}-\mathrm{N}\left[\mu \mathrm{g} \cdot \mathrm{g}^{-1}\right.$ dry soil $]-$ August $^{\mathrm{y}}$} & G. Walsertal & $10.8 \pm 3.4$ & $10.1 \pm 0.7$ \\
\hline & V. Müstair & $6.7 \pm 0.8$ & $6.1 \pm 0.8$ \\
\hline & C. Ennstal & $6.1 \pm 1.3$ & $6.8 \pm 0.7$ \\
\hline
\end{tabular}

*After values refer to significant differences within a region $(P<0.05)$. Means $\pm S D,{ }^{\mathrm{x}}: n=6,{ }^{\mathrm{y}}: n=3$

successional age. After cessation of mowing the dominant species shifted from the tussock-forming grass $B$. erectus to the vegetatively propagating grass $B$. pinnatum with extensive rhizomes and therefore highly competitive in abandoned grasslands (Grime et al. 1988).

Only a few plant species were restricted to abandoned grasslands, indicating a low habitat-specific species pool of grass-dominated successional communities. With just a few exceptions (e.g. L. bulbiferum subsp. bulbiferum), regionally rare or endangered plant species did not benefit from abandonment. Abandonment favoured tall and broad-leaved grasses (B. pinnatum, Arrhenatherum elatius) at the expense of small- to medium-sized, fine-leaved grasses (Festuca rupicola, F. rubra). A few legumes (T. medium, V. sepium) also benefited from abandonment. Vicia sepium is a scrambling legume with leaf tendrils, which is advantageous on abandoned sites. Tall herbs (especially Laserpitium latifolium) and clonally proliferating species such as Galium album were also promoted by abandonment. Based on results from this study and in accordance with 
Litter decomposition

Great Walsertal

$\mathrm{k}$

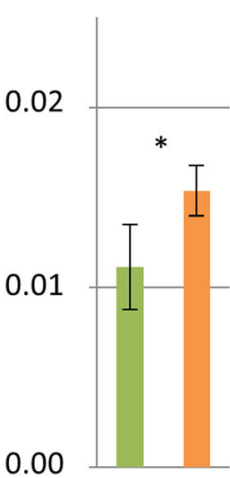

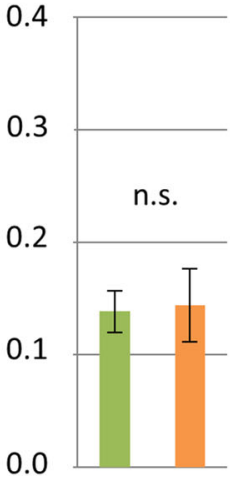

managed

Val Müstair

k

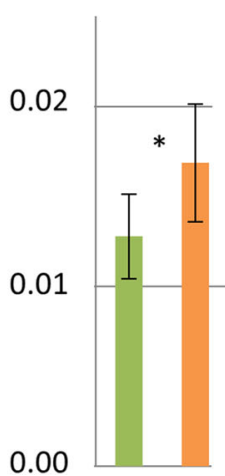

Fig. 4 Litter decomposition rate $(k)$ and stabilization factor $(S)$ in managed and abandoned grasslands in three different regions in the Eastern Alps. Means $\pm S D, n=3$ for G. Walsertal and V.

other studies (Bohner et al. 2012; Prévosto et al. 2011), the following plant attributes appear to be important in grassland succession: tall stature, leaves evenly distributed along the erect stem (erosulate plants), broad leaves, competitive strategy, perennial life cycle, below-ground reserve organs (geophytes), vegetative propagation via rhizomes (rhizomatous species), scrambling life form (leaf tendrils), tolerance to low light availability at different stages.

In the abandoned grasslands under study, there was no significant invasion of shrubs and trees even after 60 years of secondary succession. We assume that the germination and establishment of woody plants is impeded by a virtually closed sward and by accumulated necromass, retarding further succession to shrub communities. This finding is supported by several other studies (Bohner et al. 2012; Moog et al. 2002).

The managed and abandoned grasslands studied differed greatly in physiognomy and flowering phenology, which might also affect insects (Walcher et al. 2017; Hussain et al. 2018).

Topsoil changes due to abandonment

Across study regions, abandoned grasslands had significantly higher soil $\mathrm{C}_{\text {org }}$ concentrations than managed grasslands primarily due to higher rates of soil $\mathrm{C}$ inputs

abandoned

\section{Central Ennstal}

k

S
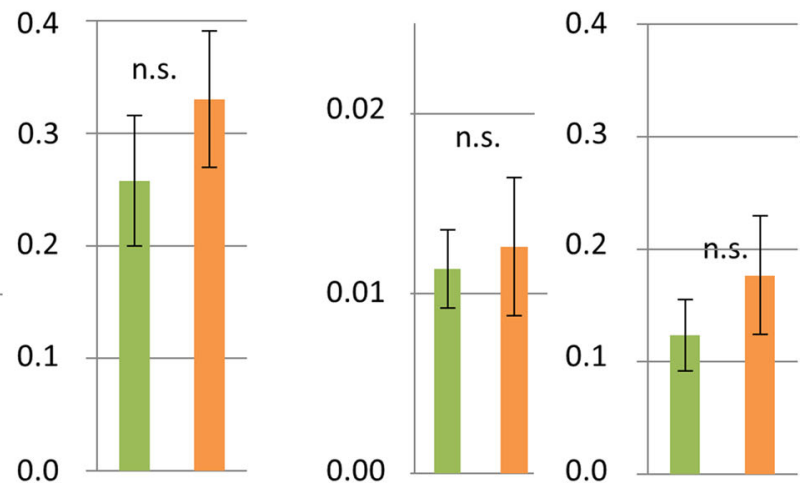

Müstair, $n=4$ for C. Ennstal. * denotes significant differences between managed and abandoned grasslands (Tukey-HSD, $P<$ 0.05), n.s. no significant differences

resulting from greater above-ground phytomass. Across study regions, abandonment increased soil C:N ratio, indicating that the cessation of mowing favours accumulation of less humified organic matter in topsoil. Since SOC accumulation generally involves the sequestration of soil N (Stevenson and Cole 1999), grassland abandonment frequently leads to enrichment of $\mathrm{N}_{\text {tot }}$ in the surface soil layer. In abandoned grasslands, the soil $\mathrm{N}$ supply was higher than in managed meadows because of higher rates of $\mathrm{N}$ inputs to the soil resulting from plant litter decomposition. At all study sites, $\mathrm{NH}_{4}{ }^{+}$was the major form of inorganic soil $\mathrm{N}$ at the time of sampling, indicating a low nitrifying capacity of the studied semidry, nutrient-poor grassland soils. Similar effects of grassland abandonment on topsoil properties were observed in many other studies (Knops and Tilman 2000; Köhler et al. 2001; Tilman 1987; Zeller et al. 2001). The higher above-ground plant biomass and the denser surface layer of necromass at abandoned sites reduced average soil temperature and increased soil moisture (Facelli and Pickett, 1991).

Soil microbial community composition (PLFA) differed significantly among study regions but was not significantly affected by abandonment. This indicates that functional groups of soil microorganisms are more strongly influenced by local abiotic site conditions than by species composition of the vegetation (litter quality), plant community productivity (litter quantity) and plant 
species richness (litter diversity). This finding is in agreement with that of other studies (De Vries et al. 2012; Zeller et al. 2001). For most of the functional groups of soil microorganisms no consistent response to abandonment was obvious except for gram-positive bacteria, gram-negative bacteria and AMF, which slightly benefited from the cessation of mowing. Abandonment increased the bacteria:fungi ratio, presumably because of an enhanced soil water and inorganic soil N supply (De Vries et al. 2012; Hackl et al. 2005). The results of our correlation analysis suggested that microorganisms benefit from a high concentration of $\mathrm{C}_{\text {org }}$ in topsoil, from an enhanced inorganic soil $\mathrm{N}$ supply and improved soil water availability, indicating that resource availability (nutrients, water) has a strong influence on soil microorganisms (De Vries et al. 2012).

Changes in litter decomposition due to abandonment

The decomposition rate of both litter types was significantly higher on abandoned than on managed plots, indicating more favourable soil environmental conditions for decomposer microorganisms in abandoned semi-dry grasslands (Zhang et al. 2008). Thus, abandonment may accelerate litter decomposition in the topsoil at least during dry periods through increased soil water availability, leading to a faster $\mathrm{N}$ cycling and hence higher grass cover (Tilman and Downing 1994) in abandoned grasslands. Under semi-dry soil conditions, the positive effect of higher soil water availability after abandonment on microbial litter decomposition might be stronger than the negative effect of lower soil temperature (Butenschoen et al. 2011; Garcia-Palacios et al. 2016). Across study regions, litter stabilization factor, which is indicative for long-term C storage (Keuskamp et al. 2013), was significantly higher on abandoned plots compared to managed plots. We assume, that abandonment of semi-natural grasslands promotes SOC sequestration in the topsoil despite higher litter decomposition rates because a higher proportion of plant litter presumably enters the permanent (passive) SOM pool (Schulze et al. 2000). Our results demonstrate that abandonment of semi-natural grasslands promotes SOC sequestration in the topsoil not only by increasing plant litter inputs to the soil (Bohner et al. 2006), but also by converting more plant litter into SOM.
Ecosystem services

The cessation of mowing promotes SOC sequestration but can have detrimental effects on ESs linked to aesthetic values, if abandonment leads to grass-dominated, less colourful plant stands and can even affect human health aspects (Arnberger et al. 2018a, b). A high aesthetic value of semi-natural grassland communities as a result of great herb diversity is hardly compatible with SOC sequestration because annual mowing without manuring over a long period together with removal of the mown biomass inevitably leads to $\mathrm{C}$ losses in the topsoil (Bohner et al. 2016). To optimize the provision of ESs at the landscape scale, a mosaic of different land-use types and management intensities, including abandoned grasslands of different successional age, seems necessary.

\section{Conclusions}

Contrary to our hypothesis, the results show that several vegetation, soil and microbial parameters display no consistent trend during secondary succession in semi-natural grasslands on semi-dry, nutrient-poor, base-rich soils under different climatic conditions. Our study shows that vegetation parameters in general respond more sensitively and less site-specific to abandonment than soil and microbial parameters at the plant community scale, making the former a more reliable indicator of successional changes. Among the studied soil parameters, $\mathrm{C}: \mathrm{N}$ ratio in topsoil seems to be the best parameter for monitoring successional changes due to abandonment.

Acknowledgements We are grateful to Michaela Djordjevic and Barbara Kitzler for the laboratory analyses. Thanks to Norbert Schuller, Edith Gruber and Doris Zitta for organizational help and to Doris Mayer for practical help in field work and sorting plant material. We thank three anonymous referees for their constructive comments, which have greatly improved the manuscript. This project was supported by the Earth-System-Science-Programme of the Austrian Academy of Sciences (Project HealthyAlps).

Funding Open access funding provided by University of Natural Resources and Life Sciences Vienna (BOKU)

Open Access This article is licensed under a Creative Commons Attribution 4.0 International License, which permits use, sharing, adaptation, distribution and reproduction in any medium or format, as long as you give appropriate credit to the original author(s) and the source, provide a link to the Creative Commons licence, and indicate if changes were made. The images or other third party 
material in this article are included in the article's Creative Commons licence, unless indicated otherwise in a credit line to the material. If material is not included in the article's Creative Commons licence and your intended use is not permitted by statutory regulation or exceeds the permitted use, you will need to obtain permission directly from the copyright holder. To view a copy of this licence, visit http://creativecommons.org/licenses/by/4.0/.

\section{References}

Arnberger A, Eder R, Allex B, Hutter H-P, Wallner P, Bauer N, Zaller JG, Frank T (2018a) Perceived health benefits of managed and unmanaged meadows in a mountain biosphere reserve - an experimental study in the Austrian Alps. eco.mont 10:5-14.

Arnberger A, Eder R, Allex B, Ebenberger M, Hutter H-P, Wallner P, Bauer N, Zaller JG, Frank T (2018b) Health-related effects of short stays at mountain meadows, a river and an urban site - results from a field experiment. Int J Environm Res Pub Health 15:2647

Bohner A, Foldal CB, Jandl R (2016) Kohlenstoffspeicherung in Grünlandökosystemen - eine Fallstudie aus dem österreichischen Berggebiet. Bodenkultur 67:225-237

Bohner A, Starlinger F, Koutecky P (2012) Vegetation changes in an abandoned montane grassland, compared to changes in a habitat with low-intensity sheep grazing - a case study in Styria, Austria. eco.mont 4:5-12

Bohner A, Öhlinger R, Tomanova O (2006) Auswirkungen der Grünlandbewirtschaftung und Flächenstilllegung auf Vegetation, Boden, mikrobielle Biomasse und Futterqualität. Bodenkultur 57:33-45

Braun-Blanquet J (1964) Pflanzensoziologie. Springer, Vienna, Austria

Butenschoen O, Scheu S, Eisenhauer N (2011) Interactive effects of warming, soil humidity and plant diversity on litter decomposition and microbial activity. Soil Biol Biochem 43: 1902-1907

De Vries FT, Manning P, Tallowin JRB, Mortimer SR, Pilgrim ES, Harrison KA, Hobbs PJ, Quirk H, Shipley B, Cornelissen JHC, Kattge J, Bardgett RD (2012) Abiotic drivers and plant traits explain landscape-scale patterns in soil microbial communities. Ecol Letters 15:1230-1239

Diekmann M (2003) Species indicator values as an important tool in applied plant ecology - a review. Basic Appl Ecol 4:493506

Ellenberg H, Weber HE, Düll R, Wirth V, Werner W, Paulissen D (2001) Zeigerwerte von Pflanzen in Mitteleuropa. Scripta Geobot 18

Facelli JM, Pickett STA (1991) Plant litter: its dynamics and effects on plant community structure. Bot Rev 57:1-32

Fischer MA, Oswald K, Adler W (2008) Exkursionsflora für Österreich, Liechtenstein und Südtirol. Biologiezentrum der Oberösterreichischen Landesmuseen, Linz, Austria

Garcia-Palacios P, Shaw EA, Wall DH, Hättenschwiler S (2016) Temporal dynamics of biotic and abiotic drivers of litter decomposition. Ecol Letters 19:554-563
Grime JP (1977) Evidence for the existence of three primary strategies in plants and its relevance to ecological and evolutionary theory. Amer Naturalist 111:1169-1194

Grime JP, Hodgson JG, Hunt R (1988) Comparative plant ecology. Unwin, London, UK

Hackl E, Pfeffer M, Donat C, Bachmann G, ZechmeisterBoltenstern S (2005) Composition of the microbial communities in the mineral soil under different types of natural forest. Soil Biol Biochem 37:661-671

Hood-Nowotny R, Umana NHN, Inselbacher E, OswaldLachouani P, Wanek W (2010) Alternative methods for measuring inorganic, organic, and total dissolved nitrogen in soil. Soil Sci Soc Amer J 74:1018-1027

Hussain RI, Walcher R, Brandl D, Jernej I, Arnberger A, Zaller JG, Frank T (2018) Influence of abandonment on syrphid assemblages in mountainous meadows. J Appl Entomol 142:450 456

Keuskamp JA, Dingemans BJJ, Lehtinen T, Sarneel JM, Hefting MM (2013) Tea Bag Index: a novel approach to collect uniform decomposition data across ecosystems. Methods Ecol Evol 4:1070-1075

Klotz S, Kühn I, Durka W (2002) BIOLFLOR-Eine Datenbank zu biologisch-ökologischen Merkmalen der Gefäßpflanzen in Deutschland. Schriftenr Vegetationsk. Bundesamt für Naturschutz, Bonn

Knops JMH, Tilman D (2000) Dynamics of soil nitrogen and carbon accumulation for 61 years after agricultural abandonment. Ecology 81: 88-98

Köhler B, Ryser P, Güsewell S, Gigon A (2001) Nutrient availability and limitation in traditionally mown and in abandoned limestone grasslands: a bioassay experiment. $P l \&$ Soil 230: 323-332

MacDonald D, Crabtree JR, Wiesinger G, Dax T, Stamou N, Fleury P, Gutierrez Lapazita J, Gibon A (2000) Agricultural abandonment in mountain areas of Europe: Environmental consequences and policy response. J Environm Managem 59: 47-69

Moog D, Poschlod P, Kahmen S, Schreiber KF (2002) Comparison of species composition between different grassland management treatments after 25 years. Appl Veg Sci 5: 99-106

Mucina L, Bültmann H, Dierßen K, Theurillat J, Raus T, Čarni A, Šumberová K, Willner W, Dengler J, García RG, Chytrý M, Hájek M, Di Pietro R, Iakushenko D, Pallas J, Daniëls FJ, Bergmeier E, Santos Guerra A, Ermakov N, Valachovič M, Schaminée JH, Lysenko T, Didukh YP, Pignatti S, Rodwell JS, Capelo J, Weber HE, Solomeshch A, Dimopoulos P, Aguiar C, Hennekens SM, Tichý L (2016) Vegetation of Europe: hierarchical floristic classification system of vascular plant, bryophyte, lichen, and algal communities. Appl Veg Sci 19:3-264

Niedrist G, Tasser E, Lüth C, Dalla Via J, Tappeiner U (2009) Plant diversity declines with recent land use changes in European Alps. Pl Ecol 202:195-210

Oelmann Y, Brauckmann H-J, Schreiber K-F, Broll G (2017) 40 years of succession or mulching of abandoned grassland affect phosphorus fractions in soil. Agric Ecosyst Environm 237:66-74

Parton W, Silver WL, Burke IC, Grassens L, Harmon ME, Currie WS, King JY, Adair EC, Brandt LA, Hart SC, Fasth B (2007) 
Global-scale similarities in nitrogen release patterns during long-term decomposition. Science 315:361-364

Poschlod P, Wallis De Vries MF (2002) The historical and socioeconomic perspective of calcareous grasslands - lessons from the distant and recent past. Biol Conservation 104:361-376

Prévosto B, Kuiters L, Bernhardt-Römermann M, Dölle M, Schmidt W, Hoffmann M, Van Uytvanck J, Bohner A, Kreiner D, Stadler J, Klotz S, Brandl R (2011) Impacts of land abandonment on vegetation: Successional pathways in European habitats. Folia Geobot 46:303-325

R Development Core Team (2014) R: A language and environment for statistical computing - Version 3.1.1, The R Foundation for Statistical Computing, Vienna, Austria

Ryser P, Langenauer R, Gigon A (1995) Species richness and vegetation structure in a limestone grassland after 15 years management with six biomass removal regimes. Folia Geobot Phytotax 30:157-167

Scherer-Lorenzen M (2008) Functional diversity affects decomposition processes in experimental grasslands. Funct Ecol 22: 547-555

Schulze E-D, Wirth C, Heimann M (2000) Managing forests after Kyoto. Science 289:2058-2059.

Stevenson FJ, Cole MA (1999) Cycles of soil. 2nd ed. John Wiley $\&$ Sons, New York

Tilman D (1987) Secondary succession and the pattern of plant dominance along experimental nitrogen gradients. Ecol Monogr 57:189-214

Tilman D, Downing JA (1994) Biodiversity and stability in grasslands. Nature 367:363-365
Walcher R, Karrer J, Sachslehner L, Bohner A, Pachinger B, Brandl D, Zaller JG, Arnberger A, Frank T (2017) Diversity of bumblebees, heteropteran bugs and grasshoppers maintained by both: abandonment and extensive management of mountain meadows in three regions across the Austrian and Swiss Alps. Landscape Ecol 32:1937-1951

Walker LR, Wardle DA, Bardgett RD, Clarkson BD (2010) The use of chronosequences in studies of ecological succession and soil development. J Ecol 98:725-736

Willner W, Roleček J, Korolyuk A, Dengler J, Chytrý M, Janišová M, Lengyel A, Aćić S, Becker T, Ćuk M, Demina O, Jandt U, Kącki Z, Kuzemko A, Kropf M, Lebedeva M, Semenishchenkov Y, Šilc U, Stančić Z, Staudinger M, Vassilev K, Yamalov S (2019) Formalized classification of semi-dry grasslands in central and eastern Europe. Preslia 91: 25-49

Zeller V, Bardgett RD, Tappeiner U (2001) Site and management effects on soil microbial properties of subalpine meadows: a study of land abandonment along a northsouth gradient in the European Alps. Soil Biol Biochem 33:639-649

Zhang D, Hui D, Luo Y, Zhou G (2008) Rates of litter decomposition in terrestrial ecosystems: global patterns and controlling factors. $\mathrm{J} \mathrm{Pl} \mathrm{Ecol} \mathrm{1:85-93}$

Publisher's note Springer Nature remains neutral with regard to jurisdictional claims in published maps and institutional affiliations. 